\title{
Reunión internacional de doctorado en estudios territoriales
}

\section{Béatriz Nates}

\section{(2) OpenEdition}

\section{Journals}

Edición electrónica

URL: http://journals.openedition.org/bifea/4002

DOI: 10.4000/bifea.4002

ISSN: 2076-5827

Editor

Institut Français d'Études Andines

Edición impresa

Fecha de publicación: 1 agosto 2007

Paginación: 311-312

ISSN: 0303-7495

\section{Referencia electrónica}

Béatriz Nates, « Reunión internacional de doctorado en estudios territoriales », Bulletin de l'Institut français d'études andines [En línea], 36 (2) | 2007, Publicado el 01 febrero 2008, consultado el 05 diciembre 2020. URL : http://journals.openedition.org/bifea/4002 ; DOI : https://doi.org/10.4000/ bifea.4002

\section{(c) $($ ) $\odot$}

Les contenus du Bulletin de l'Institut français d'études andines sont mis à disposition selon les termes de la licence Creative Commons Attribution - Pas d'Utilisation Commerciale - Pas de Modification 4.0 International. 
Événements

\section{REUNIÓN INTERNACIONAL DE DOCTORADO EN ESTUDIOS TERRITORIALES}

Quito, Ecuador, 9-11 de abril de 2007

Del 9 al 11 de abril, tuvo lugar la primera reunión internacional sobre el Doctorado en Estudios Territoriales que se realizará en la Universidad de Caldas a fines de 2008, en cooperación con varias instituciones científicas y de cooperación internacional de Perú, Brasil, México, Francia y España.

La reunión se llevó a cabo con el auspicio del Instituto Francés de Estudios Andinos (IFEA), quien ya tiene firmado un convenio de cooperación con la Universidad de Caldas. La Pontificia Universidad Católica del Perú brindó el apoyo logístico necesario para tal encuentro. La Cooperación Universitaria de la Embajada de Francia estuvo al frente de los detalles científicos y logísticos para llevar a feliz término el trabajo de tres días en la ciudad de Lima.

Se acordaron los siguientes ejes de investigación:

- Territorios y culturas

- La territorialización de las acciones

- Urbanización y procesos de metropolización

- Agrobiodiversidad

Mientras que los seminarios de formación doctoral fueron:

- Epistemología del territorio

- Metodología de la investigación y trabajo de campo

- Cognición, culturas y territorio

- Las escalas del territorio: del sujeto al mundo, del área a la red 
- Problemas de movilidad y transitividad

- Ciudadanos y sistemas expertos en los espacios de encuentro

- Territorios como espacios de la memoria y como patrimonio cultural

- Territorios étnicos, Estados y dinámicas sociales

- Diversidad territorial y paisaje

- Agricultura, biodiversidad y entornos socioculturales

- Economía espacial y desarrollo territorial

- Recursos, tecnologías y dinámicas territoriales

- Intersticios y heterotopías

Además se ofrecerán desde los distintos países cooperantes, las cátedras que abarcarán distintos problemas que competan a la Región Andina, la Región Amazónica, México y Centroamérica y a problemas socioterritoriales europeos. La próxima reunión será en la Universidad de Caldas, (Manizales, Colombia) del 27 al 31 de agosto de 2007.

Béatriz NATES 